\title{
STRUCTURAL CHARACTERIZATION OF THERMALLY STABILIZED POLY(ACRYLONITRILE) FIBERS BY MEANS OF X-RAY DIFFRACTION, FT-IR SPECTROSCOPY, AND TGA ANALYSIS Tuba DEMIREL
}

Department of Mechanical Engineering, Erciyes University, Kayseri, Turkey

ORCID NO: 0000-0002-5760-3705

Md. Mahbubor Rahman

Department of Textile Engineering,_Bangladesh University of Textiles, Tejgaon, Dhaka, Bangladesh

ORCID NO: 0000-0001-7104-9459

Prof. Dr. Ismail KARACAN

Department of Textile Engineering, Erciyes University, Kayseri, Turkey

ORCID NO: 0000-0002-9047-1011

\begin{abstract}
The structure and effects of thermally stabilized PAN original fibers were characterized utilizing a mixture of volume density, color change observations, flame tests, X-ray diffraction (XRD), infrared spectroscopy (FT-IR), and thermogravimetric analysis (TGA) measurements. The results obtained from the analysis of XRD work showed the conversion of the original molecular structure from a highly laterally ordered condition to a disordered amorphous structure. The experimental results acquired from FT-IR analysis indicated rapid and concurrent aromatization and dehydrogenation reactions assisted by the formation of oxygen-containing functional groups. TGA analysis showed a carbon yield of $72 \%$ at $1000{ }^{\circ} \mathrm{C}$. The application and use of $\mathrm{NH}_{4} \mathrm{Br}$ pretreatment are expected to increase the productivity of carbon fiber processing at lowered cost by significantly reducing the processing time necessary for the successful completion of thermal stabilization reactions.
\end{abstract}

Keywords: Stabilized PAN Fibers, Thermal Stabilization, Ammonium Bromide $\left(\mathrm{NH}_{4} \mathrm{Br}\right)$ salts, XRD, FT-IR, TGA.

\section{ÖZET}

Termal olarak stabilize edilmiş orjinal PAN liflerinin yapısı ve etkileri, hacim yoğunluğu, renk değişimi gözlemleri, alev testleri, X-1şını kırınımı (XRD), kızılötesi spektroskopi (FT-IR) ve termogravimetrik analiz (TGA) ölçümleri kullanılarak karakterize edilmiştir. XRD çalışmasının analizinden elde edilen sonuçlar, orijinal moleküler yapının yanal olarak düzenli bir durumdan tamamen düzensiz bir amorf yapıya dönüşümünü göstermiştir. FT-IR analizinden elde edilen deneysel sonuçlar, oksijen içeren fonksiyonel grupların oluşumunun yardımcı olduğu hızlı ve eş zamanlı aromatizasyon ve dehidrojenasyon reaksiyonlarını göstermiştir. TGA analizi, $1000{ }^{\circ} \mathrm{C}^{\prime} \mathrm{de} \% 7^{\prime}$ lik bir karbon verimi göstermiştir. $\mathrm{NH}_{4} \mathrm{Br}$ ön işleminin uygulanması ve kullanımının, termal stabilizasyon reaksiyonlarının başarılı bir şekilde tamamlanması için gerekli işlem süresini önemli ölçüde azaltarak düşürülmüş bir maliyetle karbon liflerinin üretkenliğini arttırması beklenmektedir.

Anahtar Kelimeler: Stabilize olmuş PAN lifler, Termal Stabilizasyon, Amonyum Bromür $\left(\mathrm{NH}_{4} \mathrm{Br}\right)$ tuzları, XRD, FT-IR, TGA.

\section{INTRODUCTION}

Carbon fibers are used as reinforcing elements in polymer, metal, and ceramic matrices (Farsani, 2012). Carbon fibers are widely used because of their low weight, low density, and high chemical resistance (Zhang et al., 2020). Carbon fiber composites have a strength to weight ratio 5 times that of American Iron and Steel Institute (AISI) 1020 steel and possess superior fatigue behavior to any metal (Sha et al., 2019). More than $90 \%$ of carbon fiber producers in the world widely use original PAN (also known as Polyacrylonitrile or acrylic) fiber (Dang et al., 2020; Haoa et 1., 2018; Bhatt and Goeli, 2017). Comonomers are required for carbon fiber formation of original PAN fibers (Farsani, 2012; Farsani et al., 2006).

Received 20 April 2021; Received in revised form 25 April 2021; Accepted I8 May 20ZI;

Available online 28June 2021;

dai: 10.46291//CONTECHvol5iss2ppl-9 
The PAN fiber is heated above $180-200{ }^{\circ} \mathrm{C}$ where an autocatalytic reaction of cyclization takes place through a free radical mechanism. The stabilization stage involves heating the PAN fiber in an oxygen atmosphere through a temperature range of 200-300 ${ }^{\circ} \mathrm{C}$, during which oxygen binds to the fiber, thus ensuring that the fiber can withstand high temperatures during the carbonization phase (Dang et al., 2020; Ge et al., 2019; Sun et al., 2009). Throughout stabilization, the original PAN fiber converts to a golden blonde color, followed by a deep brown color, and finally a dark black color (Wei et al., 2019). In the thermal stabilization step, dehydrogenation, cyclization, and oxidation reactions lead to the structural formation and then the carbonization stage includes inter cross-linking bond reactions (Karacan and Meseli, 2018, Dalton et al., 1999). Chemical methods include solutions of inorganic-organic acids, Lewis acids, bases, oxidizing compounds, and transition metal compounds. Ionic liquids are ideal for easy absorption of original fibers. Ionic liquids provide high thermal stability by providing catalysts for many chemical reactions (Maghe et., 2016). At the same time, the aqueous solution of $\mathrm{NH}_{4} \mathrm{Br}$ is an ionic liquid (Zhao and Guoxin, 2013). Halogens are added as flame retardants, which in order of decreasing effect are I, Br, Cl, and F elements, respectively (Visakh and Arao, 2015).

The aim of this study, therefore, is to examine the pre-effect of PANfibers thermal stabilization reactions using $\mathrm{NH}_{4} \mathrm{Br}$. Ammonium salts were shown to accelerate thermal stabilization before the carbonization step. Structural changes occurred at the molecular level of the PAN thread during the thermal stabilization phase. At a molecular level, the structural changes that occur during thermal stabilization of PAN fibers were carried out using a combination of TGA, FT-IR, and XRD analysis measurements. The effects of these changes were quantified by measuring the density of stabilized PAN fibers.

\section{MATERIAL AND METHODS}

\subsection{Determination of experimental parameters}

The most important parameters in the thermal stabilization method; It has been determined that the waiting time in the heat treatment, the stabilization temperature, the heat treatment in the air environment, and the heating rate. As a result, in this exploratory, it was purposed to shorten the cyclization time of the fibers by applying chemical pretreatment with $\mathrm{NH}_{4} \mathrm{Br}$ aqueous solution before the stabilization stage of the PAN fiber in addition to the basic parameters. It is also thought that energy consumption costs in the stabilization process will be reduced by chemical pretreatment. Determination of Experimental Parameters as shown in Table 1.

Table 1. Parameters using on experiments and annealing stages of PAN fibers $\mathrm{NH}_{4} \mathrm{Br}$ impregnated chemical solution.

\begin{tabular}{|c|c|c|c|c|c|c|c|}
\hline \multirow{2}{*}{\multicolumn{2}{|c|}{ Parameters }} & \multicolumn{6}{|c|}{ Stabilization temperature from 200 to $250^{\circ} \mathrm{C}$} \\
\hline & & 200 & 210 & 220 & 230 & 240 & 250 \\
\hline \multicolumn{2}{|l|}{ Stabilization in air } & $\checkmark$ & $\checkmark$ & $\checkmark$ & $\checkmark$ & $\checkmark$ & $\checkmark$ \\
\hline \multirow{6}{*}{$\begin{array}{l}\text { Stabilization time (min) } \\
\text { Experimental number (Exp.) }\end{array}$} & $\operatorname{Exp} 1$. & 5 & 5 & 5 & 5 & 5 & 5 \\
\hline & $\operatorname{Exp} 2$. & 15 & 15 & 15 & 15 & 15 & 15 \\
\hline & $\operatorname{Exp} 3$. & 30 & 30 & 30 & 30 & 30 & 30 \\
\hline & Exp 4. & 45 & 45 & 45 & 45 & 45 & 45 \\
\hline & Exp 5. & 60 & 60 & 60 & 60 & 60 & 60 \\
\hline & Exp 6. & 75 & 75 & 75 & 75 & 75 & 75 \\
\hline \multicolumn{2}{|c|}{ Heating rate in each temperature $\operatorname{step}\left({ }^{\circ} \mathrm{C} / \mathrm{min}\right)$} & 2 & 2 & 2 & 2 & 2 & 2 \\
\hline \multicolumn{2}{|c|}{$\begin{array}{l}\text { Ammonium bromide }\left(\mathrm{NH}_{4} \mathrm{Br}\right) \text { impregnated } \\
\text { pretreatment }\end{array}$} & $\checkmark$ & $\checkmark$ & $\checkmark$ & $\checkmark$ & $\checkmark$ & $\checkmark$ \\
\hline
\end{tabular}

\subsection{Materials}

The commercially produced PAN copolymer used in the present investigation incorporates composition was $90 \%$ acrylonitrile (AN) and 10\% vinyl acetate (VA) monomers. These PAN original fibers are a linear density of 59.7 
\pm 0.1 Tex per 180 filaments together with a thickness of $22 \pm 0.2 \mu \mathrm{m}$. $\mathrm{NH}_{4} \mathrm{Br}$ decomposes in aqueous solutions by applying heat through occurring two independent chemical reactions given in the formula (1) and (2).

$$
\begin{gathered}
\mathrm{NH}_{4} \mathrm{Br}(\mathrm{s}) \stackrel{\mathrm{H}_{2} \mathrm{O}}{\longrightarrow} \mathrm{NH}_{4}+(\mathrm{aq})+\mathrm{Br}^{-}(\mathrm{aq}) \\
\mathrm{NH}_{4} \mathrm{Br}(\mathrm{s}) \longrightarrow \mathrm{NH}_{3}(\mathrm{~g})+\mathrm{HBr}(\mathrm{g})
\end{gathered}
$$

Chemical pretreatment with flame retardant $5 \% \mathrm{NH}_{4} \mathrm{Br}$ aqueous halogen solution at $90{ }^{\circ} \mathrm{C}$ temperature was immersed for 1 hour. This flowchart of the experimental process was shown in Fig. 1.

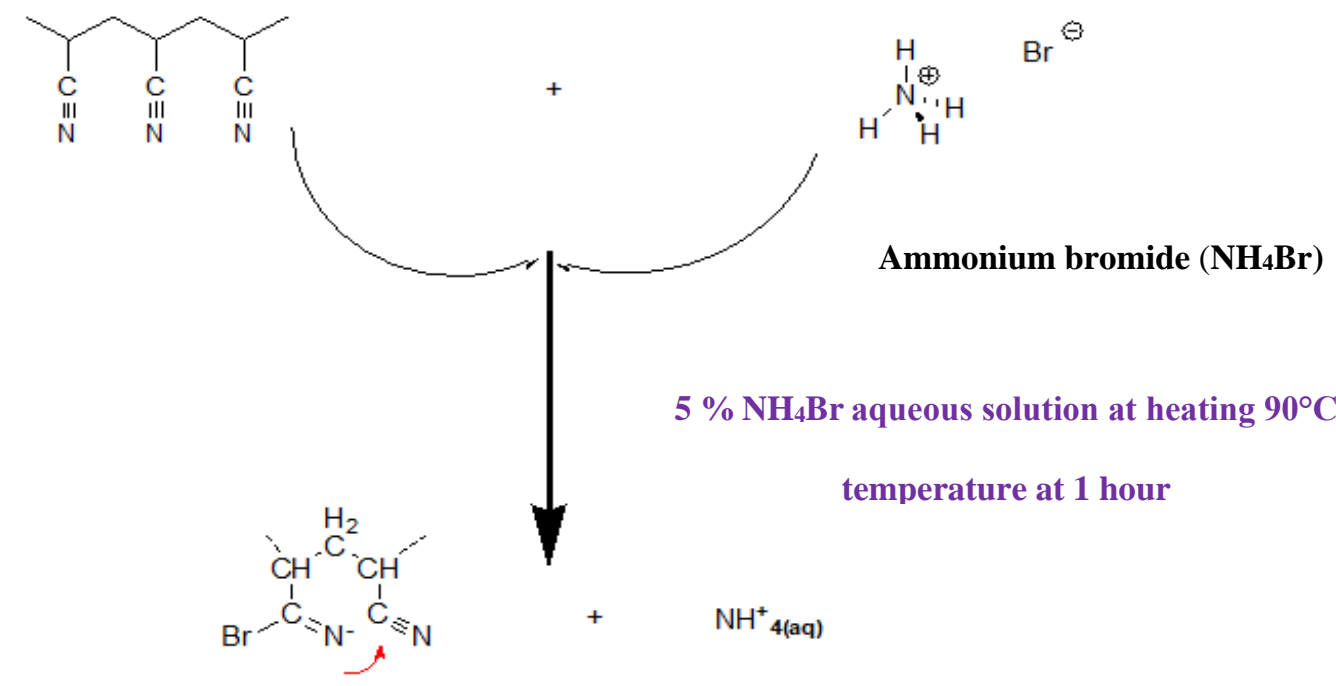

Cyclization reaction starts at the end of the

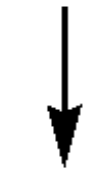

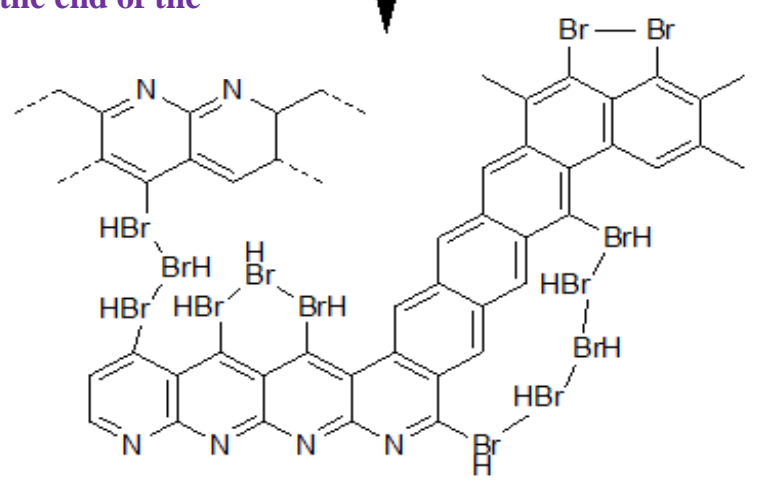

Fig. 1. The agent $\mathrm{NH}_{4} \mathrm{Br}$ halogen salt in the stabilization stage in the PAN polymer.

For $\mathrm{NH}_{4} \mathrm{Br}$ solution impregnation, we wrapped the samples in stainless steel frames. Prior to pretreatment, original PAN fibers were washed in $10 \%$ aqueous ethanol solution for 1 hour to eliminate impurities from the surface followed by washing under flowing water for 1 hour. As a final step, the samples were allowed to dry overnight. $5 \%$ (w/w) $\mathrm{NH}_{4} \mathrm{Br}$ aqueous solution was used to impregnate PAN fibers: the $\mathrm{pH}$ value of the solution was measured as 5.82 at $25^{\circ} \mathrm{C}$. Thermal stabilization of PAN fiber was carried out in air at a room temperature of $10^{\circ} \mathrm{C}$ from 200 to $250^{\circ} \mathrm{C}$ with stabilization times of $5 \mathrm{~min}, 15 \mathrm{~min}, 30 \mathrm{~min}, 45 \mathrm{~min}, 60 \mathrm{~min}$, and $75 \mathrm{~min}$, separately. A heating rate of $2{ }^{\circ} \mathrm{C} / \mathrm{min}$ was utilized to $200-250{ }^{\circ} \mathrm{C}$ followed by a cooling rate of $2{ }^{\circ} \mathrm{C} / \mathrm{min}$. The temperature rose from $10^{\circ} \mathrm{C}$ to $200-250{ }^{\circ} \mathrm{C}$ then decrease by slowly cooling to $10^{\circ} \mathrm{C}$. 


\subsection{Fiber stabilization}

Thermal stabilization process was performed using $\mathrm{NH}_{4} \mathrm{Br}$ impregnation PAN multifilament fibers via multi-step annealing approach at $250{ }^{\circ} \mathrm{C}$ for different treatment time ranging from 5 to 75 minutes. Thermal stabilization of PAN fibers was performed in an air atmosphere (Fig. 2). The multi-step approach as following:

1. Heating from 10 to $200{ }^{\circ} \mathrm{C}$ at $2{ }^{\circ} \mathrm{C} / \mathrm{min}$ holding for a given stabilization time.

2. From 200 to $210^{\circ} \mathrm{C}$ at $2^{\circ} \mathrm{C} / \mathrm{min}$.

3. From 210 to $220^{\circ} \mathrm{C}$ at $2^{\circ} \mathrm{C} / \mathrm{min}$.

4. From 220 to $230{ }^{\circ} \mathrm{C}$ at $2{ }^{\circ} \mathrm{C} / \mathrm{min}$.

5. From 230 to $240{ }^{\circ} \mathrm{C}$ at $2^{\circ} \mathrm{C} / \mathrm{min}$.

6. From 240 to $250{ }^{\circ} \mathrm{C}$ at $2{ }^{\circ} \mathrm{C} / \mathrm{min}$.

7. Cooling from $250^{\circ} \mathrm{C}$ to room temperature at $2{ }^{\circ} \mathrm{C} / \mathrm{min}$.

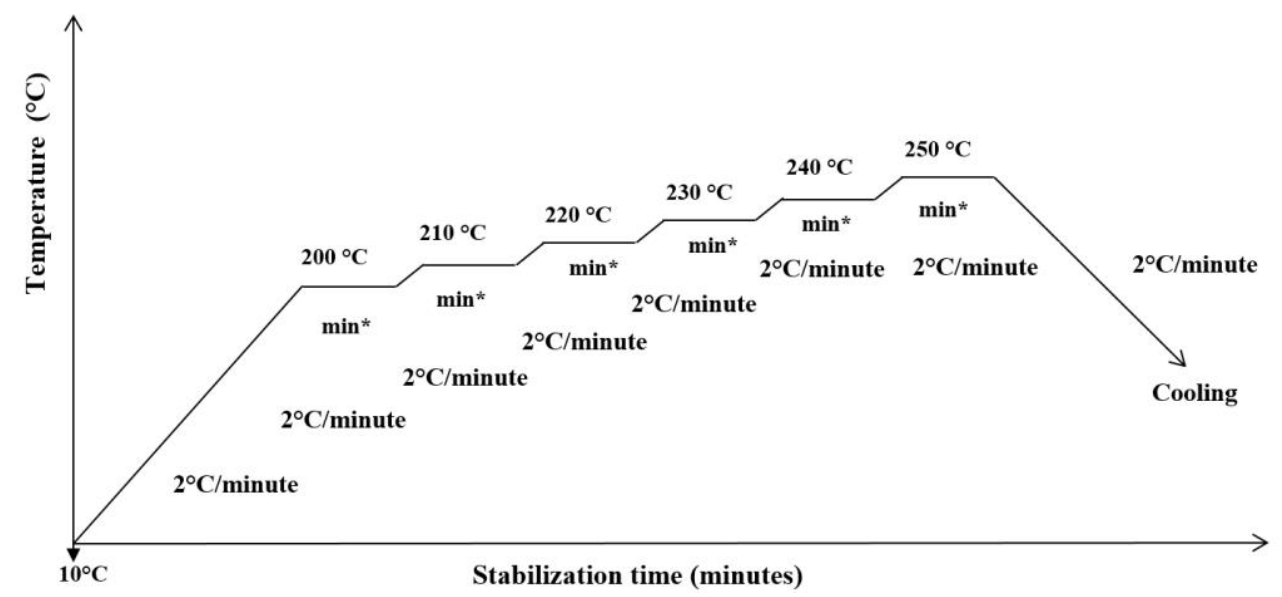

Fig. 2. Annealing stages of PAN filament impregnated chemical solution.

\section{RESULTS AND DISCUSSION}

During thermal stabilization, atmospheric oxygen accelerates cyclization and oxidation reactions. In the present investigation, the effect of $\mathrm{NH}_{4} \mathrm{Br}$ impregnation of PAN fiber was investigated in detail. The burning (nonflammability) test is a suitable pretesting method to determine textile fiber categories. Stabilized PAN fibers were directly exposed to a match flame to determine its burning rate and properties.

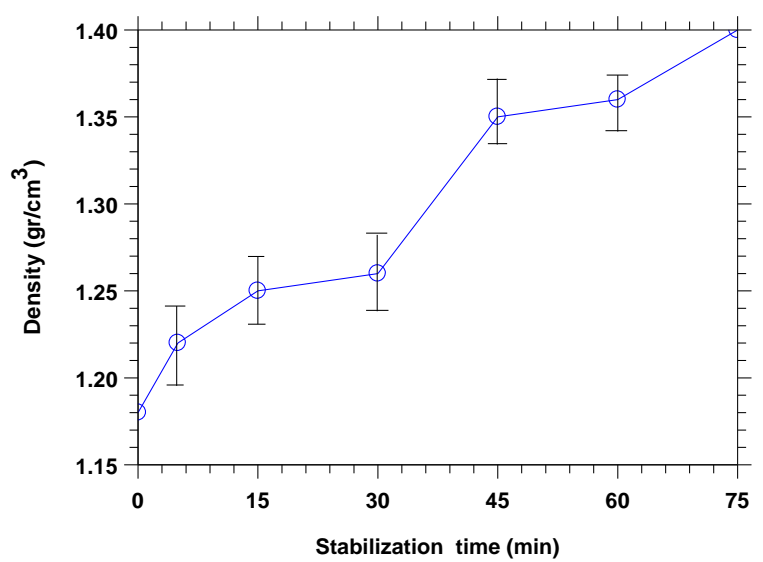

Fig. 3. Change of volume density as stabilized PAN fiber in stabilization time on-air atmosphere.

Received 20 April 2021; Received in revised form 25 April 20Z1; Accepted I8 May 2021;

Available online 28June 20Z1;

doi: 10.4629I//CDNTECHvol5iss2ppl-9 
The volume density of the original PAN fiber is $1.18 \mathrm{gr} / \mathrm{cm}^{3}$. The density values increase from 1.18 to $1.40 \mathrm{gr} / \mathrm{cm}^{3}$ in Fig. 3 because of ongoing cyclization and oxidation reactions. The density values of carbonized fibers decrease with enhancing density values of the stabilized PAN samples. It seems that high-density values of stabilized samples result in fibers with low tensile strength values due to the formation of micropores. Increasing the amount of oxygen in the atmosphere has increased the density of the fiber. Volume density of fiber shows that it is an effective approach for the evaluation of the physical properties of the stabilized PAN fiber.

\subsection{Evaluation of fiber characterization}

\subsubsection{X-ray diffraction (XRD) analysis}

XRD profiles were acquired employing nickel filtered CuKa radiation $(\lambda=0.154 \mathrm{~nm})$. The Bruker ${ }^{\circledR}$ AXS D8 X-ray diffractometer is used for XRD work using voltage and current adjustments of $40 \mathrm{kV}$ and $40 \mathrm{~mA}$, respectively. The thermal stabilization process seems to have a great influence on crystalline structure in terms of crystal dimension and degree of crystallization for the laterally ordered structure. Observation of gradually lost laterally ordered structure was made with progressing stabilization activities. Detailed analysis of fitted XRD traces of original and stabilized PAN fibers in the $5 \% \mathrm{NH}_{4} \mathrm{Br}$ solution are presented in Fig. 4 (A) and (B). The results indicate that the X-ray stabilization index enhanced very rapidly following the rising stabilization time in Fig. 4. (B). In the present work, X-ray stabilization index data were observed to rise with rising stabilization time in Fig. 4. The results presented in Fig. 4 indicate that the amounts of apparent X-ray crystallinity exhibited a decreasing trend and an increasing trend was observed in the case of amorphous fraction values. The values of X-ray crystallinity indicated a decreasing tendency starting from $19 \%$ to $5 \%$. However, the values of the amorphous fraction exhibited a reverse tendency, increasing from 81 to $95 \%$ with increasing stabilization time. XRD curves of original and stabilized PAN fibers for stabilization times are given in Fig. 4(A).

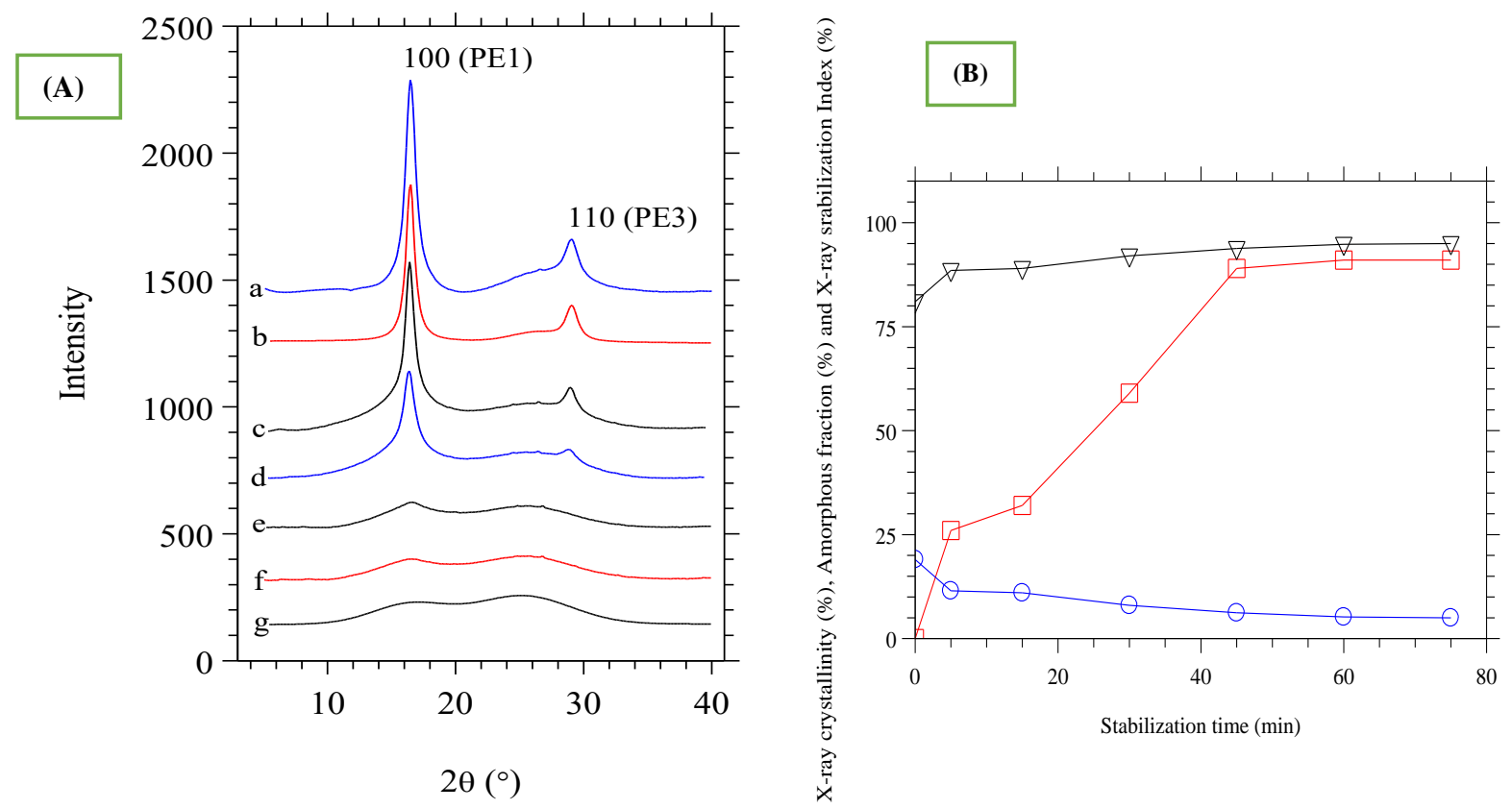

Fig. 4. (A) XRD curves of original (a), and stabilized PAN fibers impregnated in $5 \% \mathrm{NH}_{4} \mathrm{Br}$ as a function of stabilization times (in each stage) (b) $5 \mathrm{~min}$, (c) $15 \mathrm{~min}$; (d) $30 \mathrm{~min}$; (e) $45 \mathrm{~min}$; (f) $60 \mathrm{~min}$; (g) $75 \mathrm{~min}$. (B) X-ray order, amorphous ratio and X-ray stabilization Index values as a function of stabilization time. ( $\square$ ) X-ray stabilization Index (\%), (O) X-ray crystallinity (\%), and ( $\nabla)$ Amorphous ratio (\%).

\subsubsection{Thermogravimetric (TGA) analysis}

A Perkin Elmer diamond TGA system was used to obtain thermograms of the original and heat stabilized samples. Throughout the TGA experiments, the maximum temperature was $1000^{\circ} \mathrm{C}$. The heating speed was $10{ }^{\circ} \mathrm{C} / \mathrm{min}$. A

Received 20 April 2021; Received in revised form 25 April 20Z1; Accepted I8 May 2021;

Available online 28June 20Z1;

dai: I0.4629I//CONTECHvol5iss2ppl-Q 
continuous flow of nitrogen gas $(200 \mathrm{ml} / \mathrm{min})$ was kept during the experiments. Weight calibration was performed using $20 \mathrm{mg}$ standard weight at $20^{\circ} \mathrm{C}$ in both systems.
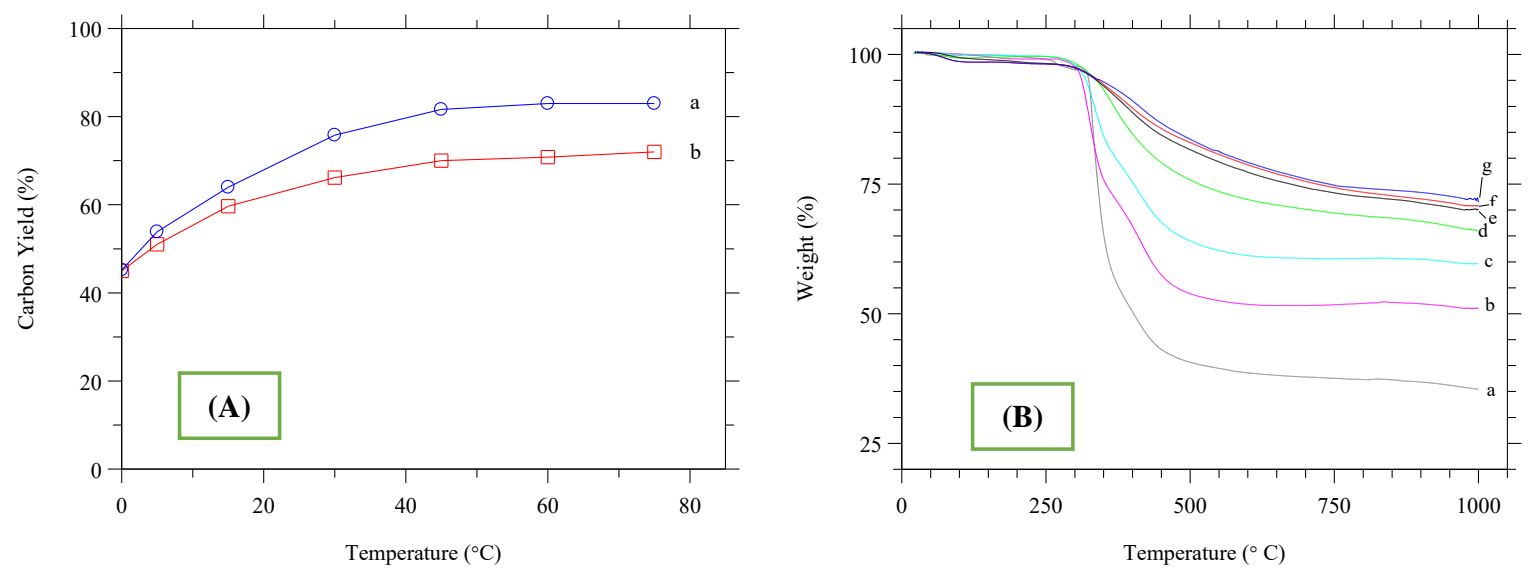

Fig. 5. (A) Comparison of carbon yields of original and stabilized $\mathrm{PAN}$ fibers impregnated in $5 \% \mathrm{NH}_{4} \mathrm{Br}$ solution, and stabilized at $250{ }^{\circ} \mathrm{C}$ by a multistep annealing approach for different stabilization period, at different temperatures (a) $500{ }^{\circ} \mathrm{C}(\mathrm{O})$ and (b) $1000{ }^{\circ} \mathrm{C}(\square)$ (B) TGA thermograms of original and stabilized PAN multifilament impregnated with $5 \% \mathrm{NH}_{4} \mathrm{Br}$ and stabilized at $250{ }^{\circ} \mathrm{C}$ by multi-step annealing approach for different stabilization times (in each stage) (a) original PAN (b) $5 \mathrm{~min} \mathrm{(c)} 15 \mathrm{~min}$ (d) $30 \mathrm{~min}$ (e) $45 \mathrm{~min}$ (f) $60 \mathrm{~min}$ (g) 75 $\min$.

Total mass loss at $1000{ }^{\circ} \mathrm{C}$ for the original PAN fiber is $55 \%$ together with the carbon efficiency of $45 \%$. TGA thermograms of $\mathrm{NH}_{4} \mathrm{Br}$ impregnated and stabilized PAN samples exhibit rising thermal stability and carbon yield due to the impact of the enhancing intermolecular. TGA thermograms presented in Fig. 5 (A) show an increase in carbon yield with the increase of stabilization time, which indicates a decrease in mass loss caused by the progressing aromatization process. Owing to the formation of a highly cross-linked and aromatized structure, thermally stabilized PAN loses mass above a broader temperature interval although the original PAN loses weight above a narrow temperature interval. A severe thermal decomposition is observed for thermally stabilized PAN fibers with a stabilization time of $5 \mathrm{~min}$ at temperatures between 300 and $450{ }^{\circ} \mathrm{C}$ with a weight loss of $63.5 \%$ at $500{ }^{\circ} \mathrm{C}$ and $56.6 \%$ at $1000{ }^{\circ} \mathrm{C}$. With the increase of stabilization time, the weight loss decreases gradually in between $50^{\circ} \mathrm{C}$ and $450{ }^{\circ} \mathrm{C}$ in Fig. 5 (B). For the 75 min stabilization time, thermally stabilized PAN fibers, weight loss becomes $17 \%$ at $500{ }^{\circ} \mathrm{C}$ and $28 \%$ at $1000{ }^{\circ} \mathrm{C}$. A comparison of the carbon efficiency for the original and $\mathrm{NH}_{4} \mathrm{Br}$ impregnated and stabilized PAN fibers at temperatures of $500{ }^{\circ} \mathrm{C}$ and $1000{ }^{\circ} \mathrm{C}$ is presented in Fig. 5 (A). Analysis of the TGA thermograms shows that due to the formation of oxidation-based crosslinking and aromatization reactions the thermally stabilized PAN obtain higher thermal stability. The results obtained here illustrate that the carbon yield value increases with the raise of stabilization time. The carbon yield value for the 5 min stabilized PAN sample was $54 \%$ and $51 \%$ at $500{ }^{\circ} \mathrm{C}$ and $1000{ }^{\circ} \mathrm{C}$, respectively. In the present experimental work, $\mathrm{NH}_{4} \mathrm{Br}$ impregnated 75 min stabilized PAN sample presents a maximum carbon yield value of $83 \%$ at 500 ${ }^{\circ} \mathrm{C}$ and $72 \%$ at $1000{ }^{\circ} \mathrm{C}$. A gradual increase of carbon yields is observed at 500 and $1000{ }^{\circ} \mathrm{C}$ for different stabilization times from 5 min to 75 min in Fig. 5 (A).

\subsubsection{Infra-red spectroscopy (FT-IR) analysis}

A Perkin Elmer ${ }^{\circledR}$ Spectrum 400 FT-IR spectrometer was used during the present investigation. For all the samples, 50 interferograms were collected and averaged. All the averaged interferograms were converted by using medium the Norton-Beer apodization function. Fiber images were performed using a 40X magnification with an optical microscope (Nikon ME 600L).

The results of non-flammability tests are presented in Fig. 6. Modification of colors confirms the existence of a thermally stabilized structure of the PAN filament. It has been observed that the fiber burning is influenced by the accelerated cyclization reactions and results in the non-burning behavior after a stabilization time of $30 \mathrm{~min}$ according to other $5 \mathrm{~min}$ and $15 \mathrm{~min}$ stabilization times (min). The mass loss that occurs throughout thermal stabilization reactions causes a decrease in fiber thickness. The stabilized PAN fiber thickness was reduced from

Received 20 April 202I; Received in revised form 25 April 20Z1; Accepted I8 May 20ZI;

Available online 28June 20Z1;

dai: ID.46291//CDNTECHval5iss2ppl-9 
22 to $14 \mu \mathrm{m}$ for a stabilization time of $75 \mathrm{~min}$. The fiber thickness diminished with raising stabilization time because of mass losses occurring during thermal stabilization reactions.

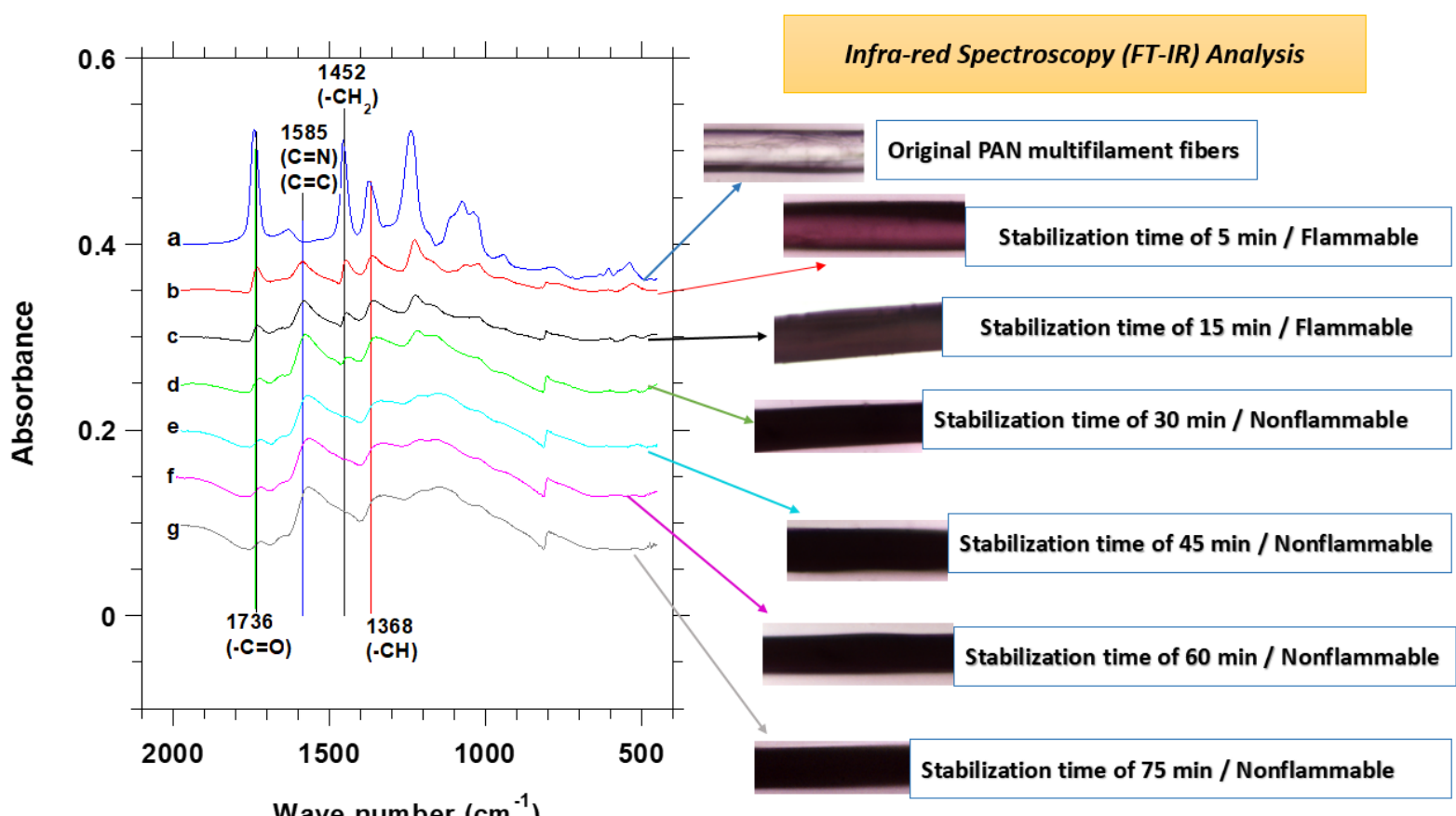

Fig. 6. Infrared spectra in the $2000-450 \mathrm{~cm}^{-1}$ region of original (a), and thermally stabilized PAN impregnated in $5 \% \mathrm{NH}_{4} \mathrm{Br}$ solution, and stabilized at $250^{\circ} \mathrm{C}$ by multistep annealing approach for different stabilization times (in each stage) (b) $5 \mathrm{~min}$ (c) $15 \mathrm{~min}$ (d) $30 \mathrm{~min}$ (e) $45 \mathrm{~min}$ (f) $60 \mathrm{~min}$ (g) $75 \mathrm{~min}$.

The infrared spectra of stabilized PAN fiber show major structural transformations as reflected in the intensities of the IR spectra with increasing stabilization time. The comparison of infrared spectrums in the area of 2000-450 $\mathrm{cm}^{-1}$ of unmodified and heat stabilized PAN multifilament fibers impregnated with $\mathrm{NH}_{4} \mathrm{Br}$ for different treatment times is presented in Fig. 6. A close examination of the IR spectrums presented in Fig. 6 indicates important structural transformations compared to the spectrum of the original PAN specimen. After a stabilization time of 5 $\min$, the carbonyl $(\mathrm{C}=\mathrm{O})$ vibration spectrum of aliphatic ketone vibration at $1736 \mathrm{~cm}^{-1}$ weakens in strength and moves to a lower position by increasing processing time till it is clearly visible as a significant conjugation absorption (Fig. 6). Because of the structural changes occurring during the thermal stabilization process, a new vibration at about $1585 \mathrm{~cm}^{-1}$ is observed in the IR spectrum of $\mathrm{NH}_{4} \mathrm{Br}$ impregnated and heat stabilized PAN sample. The infrared band positioned at $1585 \mathrm{~cm}^{-1}$ is thought to be an indication of intramolecular reactions as well as the transformation of nitrile $(\mathrm{C} \equiv \mathrm{N})$ group into nitrile $(\mathrm{C}=\mathrm{N})$ band due to the development of aromatization processes (Karacan and Erdogan, 2012). The spectrum develops further with increasing stabilization time (Fig. 6). This characteristic feature was mentioned as a possible sign of becoming a part of the conjugated structure of the carbonyl bands (Grassie and Mcguchan, 1972). During the thermal stabilization process, the C-C single bond is converted into a $\mathrm{C}=\mathrm{C}$ double-bonded species that forms aromatic structures, where oxygen is assumed to play a key role by assisting dehydrogenation reactions (Ouyang et al., 2008).

\section{CONCLUSIONS}

In this study; The stabilization phase was accelerated by using the chemical pretreatment method. Therefore, it is aimed to shorten the carbon fiber production time and to reduce the energy consumption cost. As a result of the experiments; changes in color were observed in most of the samples after stabilization. It was observed that it gained full blackening and non-flammability in $30 \mathrm{~min}, 45 \mathrm{~min}, 60 \mathrm{~min}$, and $75 \mathrm{~min}$. We observed this behavior as an indicator of cyclization in the molecular structure. Physical and chemical changes were observed in the samples during thermal stabilization. It has been observed that $\mathrm{NH}_{4} \mathrm{Br}$ salts accelerate the thermal stabilization reactions in the PAN polymer. Fiber characterization techniques; TGA, FT-IR, and XRD analysis methods were used. Additionally, an optical microscope was used to measure the fiber thickness of the samples. TGA analysis

Received 20 April 20Z1; Received in revised form 25 April 2021; Accepted I8 May 20Z1;

Available online 28June 2021;

dai: 10.46291//CONTECHvol5iss2ppl-马 
results indicated thermal stability of chemically pre-treated stabilized PAN samples compared to raw PAN polymer. At the same time, it was observed that mass loss decreased and carbon yield increased in parallel with the enhance in heat treatment time. The carbon yield of the raw PAN polymer which is $45 \%$, increased by $72 \%$ in 75 minutes as a result of chemical pre-treatment and annealing. In the FT-IR analysis, it was studied in the midinfrared region of $4000-450 \mathrm{~cm}^{-1}$ wavenumber range. In the results of the analysis of infrared spectroscopy (FTIR) data, raw PAN and stabilized pan samples were compared. It was observed that the characteristic peaks of the raw PAN polymer decreased and disappeared with the increase of the heat treatment temperature. Samples with a changed molecular structure formed cross-links as a result of the processes. As a result, $\mathrm{C}=\mathrm{C}$ bonds increased. They have a more thermally stable structure. As a result of XRD analysis, (100) and (110) reflections arising from the hexagonal structure are seen. Because PAN polymer unit cells consist of hexagonal crystal structure. According to the XRD analysis results, structural changes were observed in the PAN polymer depending on the heat treatment temperature. PAN samples lost their crystalline structure and turned into an amorphous structure. It decreases due to the increase in stabilization time and finally almost disappears at the stabilization time of $75 \mathrm{~min}$.

\section{ACKNOWLEDGMENTS}

This study was financially supported under the YÖK 100/2000 Micro and Nano Technology Materials program for the Ph.D. scholarship by the Higher Education Council of Turkey to Tuba DEMIREL. Education of Erciyes University Ph.D. was supported by a grant from the Higher Education Council of Turkey to Md. Mahbubor Rahman.

\section{REFERENCES}

Bhatt, P., Goel, A. (2017). Carbon Fibres: Production, Properties, and Potential Use., Indian Journal of Engineering and Materials Sciences, Sci. 14 (1): 52-57, http://dx.doi.org/10.13005/msri/140109

Dalton, S., Heatley, F., Budd, P.M. (1999). Thermal Stabilization of Polyacrylonitrile Fibers. Polymer, 40 (20): 5531-5543, https://doi.org/10.1016/S0032-3861(98)00778-2

Dang, W., Liu, J., Wang, X., et al. (2020). Structural Transformation of Polyacrylonitrile (PAN) Fibers During Rapid Thermal Pretreatment in Nitrogen Atmosphere. Polymers, 12(1): 63-75, https://doi.org/10.3390/polym12010063

Farsani, R.E., Shokuhfar, A., Sedghi, A. (2006). Stabilization of Commercial Polyacrylonitrile Fibres for Fabrication of Low-cost Medium-strength Carbon Fibres. E- Polymers, 6(1): 1-10, https://doi.org/10.1515/epoly.2006.6.1.1

Farsani, R.E. (2012). Production of Carbon Fibers from Acrylic Fibers. International Conference on Chemical (ICCEE'2012) March 24-25 Dubai, 310-312, http://psrcentre.org/images/extraimages/19.\%20312758.pdf

Grassie, N., Mcguchan, R. (1972). Pyrolysis of Polyacrylonitrile and Related Polymers_-v1. Acrylonitrile Copolymers Containing Carboxylic Acid and Amide Structures. European Polymer Journal, 8(2): $257-$ 269, https://doi.org/10.1016/0014-3057(72)90032-8

Ge, Y., Fu, Z., Deng, Y., Zhang, M., Zhang, H. (2019). The Effects of Chemical Reaction on the Microstructure and Mechanical Properties of Polyacrylonitrile (PAN) Precursor Fibers. Journal of Materials science 54 (1): 12592-12604, https://doi.org/10.1007/s10853-019-03781-5

Haoa, J., Liu, Y., Lu, C. (2018). Effect of Acrylonitrile Sequence Distribution on the Thermal Stabilization Reactions and Carbon Yields of Poly (acrylonitrile-co-methyl acrylate). Polymer Degradation and Stability, 147(1): 89-96, https://doi.org/10.1016/j.polymdegradstab.2017.11.010

Karacan, I., Erdogan, G. (2012). The Effect of Ethylenediamine Pretreatment on the Molecular Structure of Thermally Stabilized Polyacrylonitrile Fibers before Carbonization. Polymer Engineering \& Science, 52(3): 467-480, https://doi.org/10.1002/pen.22104

Karacan, I., Meseli, H. (2018). Characterization of Amorphous Carbon Fibers Produced from Thermally stabilized polyamide 6 fibers. Journal of Industrial Textiles, 2018; 47(6): 1185-121, https://doi.org/10.1177/1528083716682922

Maghe, M., et al. (2016). Using Ionic Liquids to Reduce Energy Consumption for Carbon Fibre Production. Journal of Materials Chemistry, 4(42): 16619-16626, https://doi.org/10.1039/C6TA06842A

Received 20 April 202I; Received in revised form 25 April 20Z1; Accepted I8 May 20ZI;

Available online 28June 2021;

dai: ID.46291//CDNTECHval5iss2ppl-9 
Ouyang, Q., Cheng, L., Wang, H., Li, K. (2008). Mechanism and Kinetics of the Stabilization Reactions of Itaconic Acid-modified Polyacrylonitrile. Polymer Degradation and Stability, 93(8): 1415-1421, https://doi.org/10.1016/j.polymdegradstab.2008.05.021

Sun, T., Hou, Y., Wang, H. (2009). Effect of Atmospheres on Stabilization of PAN Fibers. Journal of Macromolecular Science, Part A, 46(8): 807-815, https://doi.org/10.1016/j.matchemphys.2008.08.088

Sha, Y., Liu, W., Li, Y., Cao, W. (2019). Formation Mechanism of Skin-core Chemical Structure Within Stabilized Polyacrylonitrile Monofilaments. Nanoscale Research Letters, 14(93): 2-7, https://doi.org/10.1186/s11671-019-2926-X

Visakh, P.M., Arao, Y. (2015). Flame Retardants: Polymer Blends, Composites and Nanocomposites (Engineering Materials), Springer International Publishing, pp 328.

Zhao, Y., Guoxin, H. (2013). Removal of $\mathrm{SO}_{2}$ by a Mixture of Caprolactam Tetrabutyl Ammonium Bromide Ionic Liquid and Sodium Humate Solution. RSC Advances, 3(7): 2234-2240, https://doi.org/10.1039/C2RA22600F

Zhang, X., et al. (2020). Carbonization of Single Polyacrylonitrile Chains in Coordination Nanospaces. Chemical science international journal, 11(1): 10844-10849, https://doi.org/10.1039/D0SC02048F

Wei, H., Suo, X., Lu, C., Liu, Y. (2019). A Comparison of Coagulation and Gelation on the Structures and Stabilization Behaviors of Polyacrylonitrile Fibers. Journal of Applied Polymer Science, 137(19): 1-10, https://doi.org/10.1002/app.48671 